\title{
POWSTANIE I DZIAŁALNOŚĆ WYCHOWAWCZA TOWARZYSTWA GIMNASTYCZNEGO „SOKÓ£” NA PRZEŁOMIE XIX I XX WIEKU W GALICJI
}

\section{The Establishment and Educational Activity of the "Sokół" Gymnastic Society at the Turn of the $19^{\text {th }}$ and $20^{\text {th }}$ Century in Galicia}

Sum mary: The article presents the development of the "Sokól" Gymnastic Society which was established in 1867 in Lviv. The new idea, within several years, has covered the Galicia region, penetrating also into the remaining partitions. The Society's activity was also developing during the interwar period. An important factor influencing the Sokó movement increase in popularity was "Sokót" Gymnastics Guide published since 1881. It enabled, among others, promoting gymnastics and key organizational slogans. It also functioned as a link between Lviv and numerous branches, the so-called 'nests'. Latin motto "Mens sana in corpore sano" "A sound mind in a sound body" has become the leitmotif of the organisation. The Society played a significant role in promoting gymnastics and many sports disciplines. The 'nests' also became educational and cultural centers. Through promotion of physical culture, patriotic content was brought up and passed on to future generations.

Keywords: "Sokół" Gymnastic Society, "Sokól” Gymnastics Guide, the Sokół movement, sporting activity, educational activity, Galicia

${ }^{1}$ Mgr Krzysztof Ledniowski - doktorant na Wydziale Filozoficznym Uniwersytetu Jagiellońskiego w Instytucie Pedagogiki. Adres: Instytut Pedagogiki Uniwersytetu Jagiellońskiego, ul. Batorego 12, 31-135 Kraków; e-mail: k.ledniowski@gmail.com. 


\section{Wprowadzenie}

Artykuł przedstawia powstanie oraz rozwój Towarzystwa Gimnastycznego „Sokół” na przełomie XIX i XX wieku w Galicji oraz szerokie spektrum działalności wychowawczej prowadzonej w duchu narodowym, realizowanej poprzez rozwój fizyczny, oświatę oraz kulturę. Uwzględniono również wpływ czasopisma „Przewodnik Gimnastyczny "Sokół»", które odgrywało znaczącą rolę w opisywanej działalności. Na łamach przytoczonego organu prasowego podnoszono ideę połączenia rozwoju fizycznego i moralnego człowieka. Ścisłe zespolenie tych dwóch aspektów umożliwiało osiągnięcie pełnego, doskonałego bytu. Nawiązywano tym samym wprost do starogreckiego ideału kalokagatii. Aby osiągnąć fizyczną wszechstronność i wewnętrzne piękno, upowszechniano postawy, które miały doprowadzić do wskazanego celu. Promując w czasopiśmie określone ideały wychowawcze, którym przyświecało kształtowanie świadomych obywateli - żołnierzy, dążono jednocześnie do wykreowania społeczeństwa postępującego zgodnie z przyjętymi wartościami; mającego w pełni uczestniczyć w odrodzeniu państwa. Wychowanie patriotyczne i obywatelskie podejmowane przez Towarzystwo Gimnastyczne „Sokół” miało służyć Polsce i jej obywatelom. Bogactwo treści zawartych w „Przewodniku Gimnastycznym «Sokół»” ukazuje, jakie ideały wychowawcze, cele wychowania i sposoby ich realizacji - wpisujące się w polską myśl pedagogiczną - przyświecały organizacji powołanej we Lwowie w 1867 roku.

\section{Sytuacja polityczno-społeczna Galicji u schyłku XIX wieku}

W 1772 roku dokonano pierwszego rozbioru Polski. Ziemie południowo-wschodniej Rzeczpospolitej zostały włączone do monarchii Habsburgów. Stolicą nowej prowincji austriackiej został Lwów. Do 1795 roku na ziemiach pod panowaniem Rzeczpospolitej miały miejsce ważne wydarzenia wpływające na dzieje narodu: rozwój życia umysłowego, powołanie Komisji Edukacji Narodowej, kształtowanie się nowych ugrupowań politycznych, Sejm Czteroletni, targowica czy insurekcja. Polacy zamieszkujący ziemie zagarnięte przez zaborców nie uczestniczyli w zachodzących przemianach.

Po upadku Rzeczpospolitej namiastką utraconej ojczyzny stało się Księstwo Warszawskie powstałe w 1807 roku. Po klęsce Napoleona i likwidacji księstwa funkcję tę pełniło Królestwo Polskie - utworzone w 1815 roku, pozostające pod kontrolą Rosji. W latach 60. XIX wieku, w następstwie zmieniających się uwarunkowań politycznych, to ziemie zaboru austriackiego zaczęły stanowić centrum życia narodowego.

W 1846 roku Cesarstwo Austriackie włączyło terytorium Wolnego Miasta Krakowa w swe granice. Po tych wydarzeniach, aż do 1918 roku, obszar prowincji liczył $78500 \mathrm{~km}^{2}$. Kraj nosił nazwę: Królestwo Galicji i Lodomerii wraz z Wielkim 
Księstwem Krakowskim oraz Księstwem Oświęcimskim i Księstwem Zatorskim. W połowie XIX wieku Galicję zamieszkiwało około 4,8 mln mieszkańców².

Przełomowym momentem $\mathrm{w}$ historii monarchii Habsburgów był rok 1848. Wiosna Ludów, która ogarnęła znaczący obszar Europy, spowodowała m.in. wyniesienie na tron osiemnastoletniego Franciszka Józefa I, który rozpoczął nowy etap w dziejach cesarstwa. W wyniku zmian na obszarze Galicji utworzono zalążki stronnictw politycznych. We Lwowie Stanisław Smolka z Janem Dobrzańskim dali początek stronnictwu demokratów, zaś w Krakowie Adam Potocki i Antoni Zygmunt Helcel - partii konserwatywnej ${ }^{3}$.

Historię zaboru austriackiego można podzielić na erę centralizmu oraz erę autonomii. W pierwszym okresie w Galicji panował zupełny zastój gospodarczy i polityczny; dominował system folwarczno-pańszczyźniany, społeczeństwo polskie nie miało wpływu na władzę. Walka chłopów z właścicielami ziemskimi doprowadziła do krwawych wydarzeń w roku 1846, które nazwano rzezią galicyjską. Następstwem wspomnianej Wiosny Ludów było wkroczenie Austrii na drogę konstytucyjną. Załamaniu uległa przewaga wielkich właścicieli ziemskich, udział we władzy zdobyli mieszczanie, rządy absolutystyczne zaczęły powoli ustępować. Do głosu doszły narodowości wchodzące w skład monarchii. Prowincje zyskały więcej samorządności. W Galicji nastąpiło ożywienie gospodarcze, zniesienie pańszczyzny zapoczątkowało przejście do gospodarki kapitalistycznej. Z upływem lat nie tylko najbogatsi zaczęli uczestniczyć w życiu politycznym ${ }^{4}$.

Od lat 60. XIX wieku widoczny był rozwój narodowej literatury, nauki oraz sztuki. Wielu Polaków zaczęło kariery polityczne. Zasiadali w rządzie wiedeńskim, pełnili funkcje ministrów, a także premierów - współrządzili Austrią. Stanowiło to zupełne przeciwieństwo pozostałych dwóch zaborów ${ }^{5}$. Uzyskanie autonomii przez Galicję wiązało się z jej awansem; stała się ważnym polskim ośrodkiem. Z zacofanego obszaru gnębionego przed laty prowincja habsburska wybiła się na czoło starań o odrodzenie Polski.

Klęska i represje po powstaniu styczniowym (1863) w Królestwie Polskim oraz rozwój pruskiego militaryzmu zakończyły marzenia o autonomii w tych zaborach. Autonomia uzyskana przez Galicję, będąca bardziej wynikiem słabości Wiednia niż rezultatem działań polskiego społeczeństwa, spowodowała rozejście się jej z pozostałymi zaborami ${ }^{6}$. Klęska powstania styczniowego zapoczątkowała rozwój nowych koncepcji odzyskania niepodległości. W zaborze

2 Stefan Kieniewicz, Galicja w dobie autonomicznej (1850-1914): wybór tekstów (Wrocław: Wydawnictwo Zakładu Narodowego im. Ossolińskich 1952), VIII-IX.

${ }_{3}$ Marian Zgórniak, Polska w czasach walk o niepodległość (1815-1864) (Kraków: Forga Oficyna Wydawnicza 2001), 226.

${ }^{4}$ Kieniewicz, Galicja..., V-VI.

${ }^{5}$ Stanisław Grodziski, W Królestwie Galicji i Lodomerii (Kraków: Wydawnictwo Literackie 1976), 9.

6 Tamże, 8. 
austriackim zaczął narastać konflikt pomiędzy zwolennikami ustępstw wobec Wiednia, w zamian za poszerzanie swobód, a odrzucającymi ugodę zwolennikami otwartego sprzeciwu, którego celem miało być stworzenie państwa federacyjnego.

Utrata przez Austrię pozycji mocarstwa walczącego o hegemonię w Europie Środkowej stała się faktem. Węgrzy - stanowiący największą siłę - wraz z Czechami oraz Polakami poważnie zagrażali stabilności monarchii. W wyniku podjętych decyzji w 1867 roku Austria przekształciła się w Austro-Węgry z uprzywilejowaną pozycją Austriaków (austriackich Niemców) i Węgrów. Zwyciężyła wizja przebudowy polityczno-ustrojowej monarchii w kierunku centralizmu podwójnego - zwanego dualizmem. Zmieniło to dotychczasowy układ sił. Linią graniczną dla obu części państwa była rzeka Litawa. Monarchia została podzielona na Przedlitawię (część austriacka) i Zalitawię (część węgierska). Galicja pozostawała nadal pod rządami Austrii ${ }^{7}$.

Galicja nie była monolitem. We Lwowie silne wpływy miało mieszczaństwo, w Krakowie arystokracja z dominującą postawą zachowawczą. Dzięki odpowiednio skonstruowanej ordynacji wyborczej rządy sprawowało silne gospodarczo ziemiaństwo. Przebudowa monarchii nie została pozytywnie przyjęta, głównie wśród drobnomieszczaństwa, inteligencji oraz drobniejszej szlachty. Zaczęła rodzić się nowa siła sprzeciwiająca się prowadzonej polityce w Galicji. W kontekście tych nastrojów w 1868 roku założono we Lwowie Towarzystwo Narodowo-Demokratyczne, skupiające wokół siebie koła liberalno-demokratyczne oraz emigrację postyczniową. Na czele Towarzystwa stał Franciszek Smolka ${ }^{8}$.

W galicyjskiej polityce ostateczny triumf odniosła koncepcja głosząca lojalizm wobec cesarza Franciszka Józefa I. Krakowscy konserwatyści zrezygnowali z polityki niepodległościowej. Również liczna rzesza inteligencji popierała tę drogę . Odłam konserwatystów z zachodniej części kraju zyskał miano stańczyków. Nowa grupa zaczęła obsadzać najważniejsze stanowiska i nadawać ton polskiej polityce. Liberalne mieszczaństwo polskie pogodziło się z porażką. Wzywano do rozpoczęcia pracy nad wewnętrznym rozwojem kraju. Lojalność w stosunku do Wiednia, wyrażona w piśmie Teka Stańczyka oraz rozwijana przez szkołę historyczną krakowską, ugruntowała się u schyłku lat 70. XIX wieku na dłuższy czas ${ }^{10}$.

W następstwie ewolucji monarchii habsburskiej w kierunku federalistycznym nowe władze umożliwiły uchwalenie szeregu ustaw rozbudowujących ustrój autonomiczny Galicji. Zmiany te były korzystne dla ziemiaństwa, dając mu wyraźnie uprzywilejowaną pozycję, umożliwiając realizację swych idei. Wzmocnienie

7 Józef Buszko, Galicja 1859-1914. Polski Piemont? (Warszawa: Krajowa Agencja Wydawnicza 1989), 1-3.

${ }^{8}$ Kieniewicz, Galicja..., XXI-XXII.

9 Tamże, XIX.

${ }_{10}$ Buszko, Galicja 1859-1914..., 8-9. 
ziemiaństwa osłabiało polskich chłopów i Ukraińców na forum sejmowym. Ustawy krajowe miały być ogłaszane w języku polskim oraz ukraińskim i niemieckim. Wprowadzone zmiany dotyczyły m.in. władz samorządowych; powołano samorząd gminny i powiatowy, stworzono tzw. obszary dworskie wydzielone z gmin co skutkowało oddaniem właścicielom majątków nadzoru nad wsią. Zatwierdzone ustawy rozbudowały aparat autonomiczny Galicji, który stał się instrumentem panowania najbogatszej warstwy ${ }^{11}$. W 1867 roku wprowadzono przepisy o stowarzyszeniach, które zaowocowały zwiększeniem aktywności społecznej. W tym samym roku powołano Radę Szkolną Krajową, kierującą szkolnictwem ludowym i średnim.

W 1869 roku w miejsce języka niemieckiego wprowadzono język polski jako urzędowy dla władz administracyjnych, policyjnych i sądowych. W 1871 roku powołano resort ministra dla Galicji. W 1873 roku rozpoczęła w Krakowie działalność Akademia Umiejętności. Dokonano również polonizacji Uniwersytetu Jagiellońskiego oraz lwowskich uczelni wyższych - uniwersytetu i politechniki ${ }^{12}$. Była to istotna zmiana dotychczasowej polityki austriackiej - dawała nadzieje na rozwój polskiej nauki.

W roku 1873 kształt społeczno-polityczny galicyjskiej autonomii został ostatecznie ustalony. Wprowadzono bezpośrednie wybory do Rady Państwa. Dotychczas był to organ władzy składający się z delegacji poszczególnych sejmów krajowych. W wyniku zmian sejm galicyjski utracił bezpośredni wpływ na parlament centralny. Stefan Kieniewicz tak opisuje zakończoną walkę o autonomię:

Na skutek rozkładu absolutyzmu w monarchii habsburskiej Galicja uzyskała szereg urządzeń lokalnych: Sejm, Wydział Krajowy, Radę Szkolną, rady powiatowe. Uzyskała możność załatwiania we własnym zakresie niektórych spraw gospodarczych i kulturalnych. Spolszczyła także administrację i szkolnictwo, chociaż obie te służby pozostały zależne od wiedeńskiego rządu. Zdobycze te dawały Galicji, najbardziej zaniedbanej dotąd części Polski, jakie takie możliwości swobodnego rozwoju. Jednakże zdobycze te znalazły się w ręku jednej tylko, wąskiej grupy społecznej, która miała je wykorzystać dla własnych tylko, klasowych interesów ${ }^{13}$.

Rozwój gospodarczy Galicji pod koniec XIX wieku nadal pozostawał na niskim poziomie. Ziemiaństwo rządzące Galicją obawiało się rozwoju przemysłu fabrycznego i odpływu mieszkańców ze wsi do miast, czego konsekwencją byłby brak chętnych do pracy na folwarkach. Obawiano się również rozwoju ruchu socjalistycznego ${ }^{14}$.

${ }^{11}$ Józef Buszko, Od niewoli do niepodległości (1864-1918) (Kraków: Forga Oficyna Wydawnicza 2001), 108-109.

12 Tamże, 112.

${ }^{13}$ Kieniewicz, Galicja..., XXV.

${ }^{14}$ Buszko, Od niewoli..., 41. 
Przełom XIX i XX wieku to nasilająca się walka o złamanie dominującej roli ziemiaństwa oraz usunięcie reliktów feudalizmu. Zbyt wolny rozwój przemysłu nadal nie zmieniał struktury społecznej - około $75 \%$ społeczeństwa utrzymywało się z rolnictwa. Galicja była krajem przeludnionym, co skutkowało masową emigracją. Wzmagała się agitacja polityczna. Hasła poprawy warunków pracy i bytu stawały się powszechne. Ruch ludowy wzrastał na sile ${ }^{15}$.

W Galicji powstały partie ruchu socjalistycznego i chłopskiego. W 1892 roku utworzono Galicyjską Partię Socjaldemokratyczną, a w 1895 roku Stronnictwo Ludowe. Na fali wzrostu nastrojów radykalizmu społecznego i narodowego przybyli do Galicji przedstawiciele Ligi Narodowej. Głównym hasłem narodowych demokratów było zwalczanie ukraińskich postulatów. Galicyjscy endecy zwalczali również socjalistów i ludowców. Zmiany zachodzące na scenie politycznej były widoczne już w 1897 roku, kiedy to w wyniku przeprowadzonych wyborów do parlamentu wiedeńskiego weszła grupa polskich opozycyjnych posłów z Ignacym Daszyńskim na czele. Tym samym rozpoczął się okres ostrej publicznej krytyki rządów konserwatywno-ziemiańskich w Galicji, co nie miało dotychczas miejsca. W pierwszych latach XX wieku narastał konflikt socjalistów z narodowcami. Wzrastało również niezadowolenie mas robotniczych i chłopskich z rządów konserwatystów. Dochodziło do licznych strajków ${ }^{16}$.

Przesilenie nastąpiło w momencie wybuchu rewolucji w Rosji w 1905 roku. Społeczeństwo polskie, ukraińskie i żydowskie zareagowało żywo. Demonstracje ogarnęły Kraków, Lwów oraz ważniejsze miasta galicyjskie. Uciekający z Królestwa rewolucjoniści szukali schronienia w Galicji. Do zamieszek doszło również w Wiedniu. Żądano zmiany prawa wyborczego. Wybory miały być: powszechne, równe, tajne i bezpośrednie. Zmiany miały objąć mężczyzn, którzy ukończyli 24 lata i zamieszkiwali co najmniej rok na terenie okręgu wyborczego. Cesarz zaakceptował reformę; pierwsze wybory według nowych zasad odbyły się w $1907 \mathrm{roku}^{17}$.

Dynastia Habsburgów chyliła się ku upadkowi; nadchodził czas wielkich zmian. Wprowadzenie autonomii w Galicji doprowadziło do wzrostu aktywności społecznej; zakładano m.in. stowarzyszenia skupiające ludzi wokół ważnych dla nich kwestii. Polacy nie zapomnieli o dążeniach niepodległościowych. Na fali przemian doszło we Lwowie do powstania organizacji gimnastycznej, która w ramach prowadzonej wieloaspektowej działalności kształtowała kolejne pokolenia Polaków.

\footnotetext{
15 Tamże, 194-196.

16 Tamże, 196-198, 202-207.

17 Tamże, 257, 259, 266.
} 


\section{Powstanie Towarzystwa Gimnastycznego „Sokół”}

Wiek XIX przyniósł rozwój wychowania fizycznego. Zdrowiem społeczeństwa oraz kondycją fizyczną, głównie ze względów militarnych, zaczęły się interesować środowiska wojskowe. Postęp nauk medycznych i pedagogicznych dał kulturze fizycznej odpowiednie podstawy naukowe. W XIX stuleciu na terenie Europy dominowała gimnastyka niemiecka i szwedzka, w Anglii rozwijał się sport i gry sportowe $^{18}$.

Polska kultura fizyczna w okresie zaborów nie miała możliwości rozwoju. Reformy wprowadzone przez Komisję Edukacji Narodowej, z powodu upadku Rzeczpospolitej, zostały zaniechane. Zaborcy nie troszczyli się o kondycję zdrowotną polskiego społeczeństwa. Brak własnych instytucji zaważył na zaniedbaniu tej dziedziny. Skutkowało to m.in. brakiem zainteresowania mieszkańców Galicji oraz pozostałych zaborów działalnością bardziej światłych lekarzy i pedagogów propagujących aktywność ruchową ${ }^{19}$. Nie wpływało to korzystnie na pionierskie poczynania osób chcących iść z postępem czasu. Społeczeństwo było nieświadome korzyści płynących z rozwoju fizycznego człowieka. Z czasem sytuacja zaczęła jednak ulegać zmianie. Polacy dostrzegli w gimnastyce potencjał, który można wykorzystać w walce o wolność.

Idea stowarzyszeń narodowo-gimnastycznych pojawiła się w Europie. Sprzyjały temu zachodzące przeobrażenia społeczno-gospodarcze, polityczno-ustrojowe i kulturalno-oświatowe. W rozwoju narodowych systemów gimnastycznych widoczne były co najmniej dwa zasadnicze nurty. Pierwszy dotyczył narodów posiadających suwerenny byt państwowy - ruch gimnastyczny i kultura fizyczna miały wzmacniać potęgę gospodarczą i polityczną. Drugi charakteryzował kraje podbite - miał wzmacniać naród oraz dążenia niepodległościowe ${ }^{20}$.

Rozwój wychowania fizycznego na ziemiach polskich związany jest z drugim nurtem. Łączy się ściśle z ruchem sokolim, który narodził się w Czechach. Kryzys monarchii austriackiej przyczynił się do wprowadzenia zmian zwiększających autonomię krajów wchodzących w jej skład, w rezultacie nastąpił wzrost aktywności społecznej i kulturowej poprzez rozwój wielu instytucji. W 1862 roku powstało Praskie Zrzeszenie Gimnastyczne, które przybrało niebawem nazwę „Sokół”. Ideologię oraz statutowe zadania stowarzyszenia wyrażało popularne hasło: krzepmy się ${ }^{21}$.

${ }^{18}$ Jan Snopko, Polskie Towarzystwo Gimnastyczne „Sokól” w Galicji 1867-1914 (Białystok: Wydawnictwo Uniwersytetu w Białymstoku 1997), 17.

19 Tamże, 25-27.

${ }^{20}$ Kazimierz Toporowicz, „Zarys dziejów «Sokoła» na ziemiach polskich w latach 1867-1947”, w: Z dziejów Towarzystw Gimnastycznych „Sokół”, red. Zdzisław Pawluczuk (Gdańsk: Wydawnictwo Pionier 1996), 7-8.

${ }^{21}$ Ryszard Wroczyński, Powszechne dzieje wychowania fizycznego i sportu (Wrocław: Wydawnictwo BK 2003), 189-190. 
Nowy ruch szybko zyskał naśladowców, szczególnie wśród narodów słowiańskich. Główne kierunki działań zakładały stworzenie ośrodków wychowania fizycznego oraz aktywność w kwestiach narodowo-wyzwoleńczych. Dostrzegano konieczność kształcenia przyszłych pokoleń. Jedna z zasad mówiła o potrzebie wykorzystania, niezaprzepaszczenia swych zdolności i talentów ${ }^{22}$.

Ożywienie aktywności społecznej dzięki wprowadzanym zmianom było widoczne również w zaborze austriackim. Stanisław Szczepanowski tak opisywał dotychczasową sytuację:

Galicya przygnieciona od 1772 do 1866 zmorą biurokracyi niemieckiej, zgoła nie posiadała własnych tradycyi pracy obywatelskiej. Cokolwiek w tym kierunku zdziałano, było tylko odbiciem myśli i przykładów zaczerpniętych z głównego ogniska rozwoju narodowego - z Warszawy. Natomiast jak chwasty rozwinęly się bujnie dwie tradycje anti-obywatelskie, wręcz sprzeczne z porozbiorowym rozwojem, ducha narodowego ${ }^{23}$.

Pozytywne skutki zmian wyrażały się m.in. poprzez wzrost aktywności społecznej w zakresie wychowania, oświaty oraz ochrony zdrowia ${ }^{24}$. W tym czasie we Lwowie powstawało wiele organizacji i stowarzyszeń, które miały być czynnikiem spajającym i integrującym społeczeństwo, miały wzmacniać również siłę narodu, a tym samym zwiększać szansę jego przetrwania ${ }^{25}$.

Z inicjatywy lwowskiej młodzieży akademickiej w latach 60. XIX wieku założono kółko dla uprawiania gimnastyki oraz szermierki. Na gruncie prowadzonej aktywności, przy poparciu środowiska inteligenckiego i mieszczańskiego, doszło do powołania w stolicy Galicji pierwszego na ziemiach polskich Towarzystwa Gimnastycznego (termin „Sokół” wszedł do oficjalnej nazwy w 1869 roku). 7 lutego 1867 roku nastąpiło zatwierdzenie statutu stowarzyszenia ${ }^{26}$. Dzięki zaangażowaniu lokalnych środowisk udało się skupić wokół zainteresowania aktywnością fizyczną grupę osób prowadzących działalność wykraczającą poza hasła propagujące gimnastykę. Co ważniejsze, działalność ta mogła być prowadzona legalnie.

Powołanym stowarzyszeniem kierował zarząd (wówczas nazywany wydziałem) z prezesem na czele - pierwszym został Józef Milleret. Funkcje władzy ustawodawczej pełniło walne zgromadzenie członków Towarzystwa. W roku

22 Tamże, 191.

23 Stanisław Szczepanowski, Nędza Galicyi w cyfrach i program energicznego rozwoju gospodarstwa krajowego (Lwów: nakładem autora 1888), VII, https://www.sbc.org.pl/dlibra/publication/37606/edition/34263/content?ref=desc (dostęp: 6.03.2019).

24 Wroczyński, Powszechne..., 194.

25 Snopko, Polskie Towarzystwo..., 34.

26 Kazimierz Toporowicz, „Geneza Towarzystwa Gimnastycznego «Sokół» na ziemiach polskich. Powstanie «Sokoła» we Lwowie”, w: Zarys dziejów Sokolstwa Polskiego w latach 1867-1997, red. Eligiusz Małolepszy, Zdzisław Pawluczuk (Częstochowa: Wydawnictwo WSP 2001), 11-13. 
założenia było ich $125^{27}$. Od 1885 roku również kobiety mogły należeć do organizacji na równi z mężczyznami. Początkowo uczestniczyły tylko w ćwiczeniach gimnastycznych ${ }^{28}$.

Głównym symbolem Towarzystwa był sokół, odwzorowany z godła organizacji czeskiej, widocznie jednak się różniący. Sokół do momentu odzyskania przez Polskę niepodległości symbolizował Orła Białego - zakazane godło narodowe. Bez względu na okres w historii Polski emblemat „Sokoła” miał wymowę niepodległościową oraz patriotyczno-narodową ${ }^{29}$.

Genezy powstania organizacji we Lwowie należy szukać w sytuacji po upadku powstania styczniowego - poczuciu załamania i apatii. Wpływ miały również hasła pozytywistyczne, wzywające do pracy organicznej. Odrzucono walkę, wybrano inną drogę. Tak opisuje początki i główne założenia organizacji uczestnik tamtych wydarzeń Tadeusz Romanowicz:

Hasłem stała się praca. Ta praca miała być organiczną. A jeżeli ma być organiczną, to musi obejmować całość tego organizmu - musi zwracać się ku wzmocnieniu wszystkich czynników jego zdrowego rozwoju. Więc musi sięgnąć wszerz i w głąb, inaczej organiczną nie będzie, ale chorobliwie rozwijać będzie jedne części zaniedbując inne. Więc musi objaḉ równocześnie duchowe, moralne, fizyczne i ekonomiczne objawy i warunki narodowego życia, inaczej potęgować będzie tylko niektóre funkcye żywotne organizmu tego, gdy inne samem niewykonywaniem zamrą. [...] przeto ta praca ma być środkiem do wyższych celów narodowych, nie zaś celem sama dla siebie ${ }^{30}$.

Zgodnie z powyższym idea ruchu sokolego zakładała, że rozwój fizyczny człowieka umożliwi również rozwój moralny i duchowy. Jako dewizę przyjęto łacińską sentencję rzymskiego poety Juwenalisa "Mens sana in corpore sano" (W zdrowym ciele zdrowy duch), która miała podkreślić cel działalności - jedność fizycznego oraz duchowego rozwoju. Można tu dostrzec bezpośrednie nawiązanie do kalokagatii - starogreckiego ideału wychowania. Wykorzystywanie siły fizycznej nie przyświecało ideowym deklaracjom. Podkreślano, że spełniając swe zadania, Towarzystwo staje się cząstką organiczną narodowej pracy ${ }^{31}$.

Początki lwowskiego „Sokoła” wiążą się ściśle z eksponowaniem rozwoju fizycznego. Zgodnie z pierwszym paragrafem statutu Towarzystwa celem

${ }^{27}$ Jan Snopko, Dobiesław Dudek „Rozwój ruchu sokolego w zaborze austriackim”, w: Zarys dziejów Sokolstwa Polskiego..., 13.

${ }_{28}$ Snopko, Dudek, „Rozwój...”, 20.

${ }_{29}$ Mariusz Gizowski, „Symbolika ideograficzna sokolstwa polskiego”, w: 130 lat Sokolstwa Polskiego, Polskie Towarzystwo Gimnastyczne „Sokól”, red. Andrzej Łopata (Kraków: Polskie Towarzystwo Gimnastyczne „Sokól” 1997), 37, 41.

${ }^{30}$ Księga pamiątkowa ku uczczeniu dwudziestej piątej rocznicy założenia Towarzystwa Gimnastycznego "Sokól” we Lwowie, autor wstępu Tadeusz Romanowicz (Lwów: Nakładem Towarzystwa Gimnastycznego „Sokół” 1892), 6, https://www.sbc.org.pl/dlibra/publication/10742/edition/10264/ content (dostęp: 6.03.2019).

31 Toporowicz, „Geneza...”, 13. 
organizacji było: „[...] pielęgnowanie i rozwijanie gimnastyki wspólnymi ćwiczeniami, wspólnymi wycieczkami, śpiewem i szermierką" ${ }^{32}$. Znajdujemy również informację, że „W Towarzystwie będą się odbywać ćwiczenia straży ogniowej”33. Skupienie się na kwestiach związanych $\mathrm{z}$ gimnastyką miało odwrócić zainteresowanie władz nową organizacją. Głoszenie haseł patriotycznych mogło zaszkodzić powołanemu stowarzyszeniu. Jednak osoby tworzące organizację nie ukrywały dążeń narodowych. Ze względu na ograniczone możliwości ich manifestowania skupiono się na formowaniu moralnym, fizycznym oraz duchowym młodego pokolenia. Miała w tym pomóc gimnastyka higieniczno-racjonalna i wychowawcza ${ }^{34}$.

Od początku zdawano sobie sprawę z zagrożeń, jakie mogły spotkać nowo powstałą organizację - przestrzegano przed wewnętrznymi sporami, broniąc jednocześnie jej apolityczności. W różnych wizjach politycznych widziano największe zagrożenie. Zwracano uwagę na promowanie wartości narodowych, wzywając do wspólnego działania. Jan Dobrzański, zaangażowany w powstanie stowarzyszenia, pisał:

[...] Towarzystwo gimnastyczne powinno dbać o to, aby, nie mając nic wspólnego z polityką, wykluczać ją zgoła z grona członków. Dbajmy o to, aby nadać i zachować Towarzystwu cechę narodową, a obojętną jest i powinno być rzeczą, czy wydziałowy lub członek liczy się do postępowców lub konserwatystów, do białych lub czerwonych. Wybierajmy takich, którzyby bez względu na stronnictwo, do którego należą, najlepiej Towarzystwem kierować umieli. Starajmy się nie wykluczać nikogo, lecz przeciwnie zespolić, połączyć wszystkie stronnictwa w jedno wielkie, silne stronnictwo ruchu gimnastycznego ${ }^{35}$.

Ukrywanie prawdziwych celów działalności, które przyświecały powołaniu stowarzyszenia, było świadomym działaniem. W obawie przed niezatwierdzeniem statutu, a następnie przed rozwiązaniem Towarzystwa, zarówno w odezwach, artykułach dziennikarskich, jak i w podaniach do władz nie poruszano kwestii mogących wzbudzić podejrzenia ${ }^{36}$. Prawdziwe intencje przyświecające organizacji były widoczne w wieloaspektowej działalności. Przygotowywano m.in. zebrania towarzyskie, obchody rocznic narodowych czy wieczorki literackie. W ciągu kilkunastu lat stworzono infrastrukturę, umożliwiając wykorzystanie

${ }^{32}$ Statut Towarzystwa Gimnastycznego we Lwowie (Lwów 1867), 3, http://dlibra.biblioteka.tarnow.pl/Content/697/sk_46_02.pdf (dostęp: 6.03.2019).

${ }_{33}$ Tamże.

34 Joanna Kuriańska-Wołoszyn, Leonard Nowak, Gimnastyka w Polsce w latach 1919-1939 (Poznań: Wydawnictwo WSPiA 2013), 39.

${ }_{35}$ Michał Terech, Zarys dziejów sokolstwa polskiego (Warszawa: Nakładem Związku Towarzystw Gimnastycznych „Sokół” w Polsce 1932), 7, http://www.wbc.poznan.pl/dlibra/plain-content?id=273583 (dostęp: 6.03.2019).

36 Tamże. 
posiadanych pomieszczeń jako sal gimnastycznych, które zostały odpowiednio wyposażone $^{37}$.

Kazimierz Toporowicz, opisując w zwięzły sposób główne założenia ruchu sokolego, ukazuje jego całościowy obraz:

Fizyczny rozwój człowieka traktowano jako podstawę jego duchowego i moralnego rozwoju. Rozwój fizyczny, moralny i duchowy społeczeństwa polskiego traktowano jako środek do osiągnięcia wyższych celów narodowych nie zaś jak cel sam w sobie. Wychowanie w duchu narodowym zdrowego moralnie i fizycznie młodego pokolenia Polaków, uznali „Sokoli” za najwyższą wartość społeczną i swoje posłannictwo. Owe wzniosłe cele zamierzali realizować $\mathrm{w}$ atmosferze patriotyzmu, demokratyzmu i solidaryzmu społecznego oraz w duchu głębokiej religijności ${ }^{38}$.

\section{Rozwój i działalność Towarzystwa}

Początki powołanej organizacji były trudne. Największym problemem był brak własnego budynku oraz wykwalifikowanych nauczycieli gimnastyki. Do tego dochodziły problemy finansowe. Jak wskazuje Ryszard Wroczyński, rozwój „Sokoła" od lat 80. spowodowany był dwoma czynnikami. Pierwszym było znaczenie organizacji jako ośrodka polskiego życia narodowego, drugim powiązanie z polityką Rady Szkolnej Krajowej, która w swym początkowym okresie działania wiele uwagi poświęcała unowocześnieniu szkolnictwa w Galicji; dbając głównie o stan higieny i upowszechnianie systemów gimnastycznych ${ }^{39}$ wśród młodzieży ${ }^{40}$.

Początki działalności „Sokoła” przypadły na okres zmiany polityki oświatowej w Galicji. W związku z brakiem w szkołach odpowiednich pomieszczeń ćwiczenia były organizowane i prowadzone przez Towarzystwo Gimnastyczne „Sokół”, podobnie jak kursy dla nauczycieli gimnastyki. Stowarzyszenie okazało się pionierem w opracowaniu programu oraz metodyki nowego przedmiotu - gimnastyki. Stworzono polską terminologię ćwiczeń oraz specjalistyczne nazewnictwo ${ }^{41}$. Znaczenie działaczy ruchu sokolego w tym zakresie jest nie do przecenienia.

Do czołowych teoretyków i metodyków w tej dziedzinie należeli, wywodzący się z ruchu sokolego, pedagodzy, lekarze i higieniści, m.in.: Edmund Cenar, Henryk Jordan, Wenanty Piasecki oraz w późniejszym okresie Eugeniusz Piasecki

${ }^{37}$ Kajetan Hądzelek, Ryszard Wroczyński, Główne kierunki rozwoju wychowania fizycznego od końca XVIII wieku do 1918 roku (Wrocław: Zakład Narodowy im. Ossolińskich - Wydawnictwo 1968), XXXIII-XXXIV.

38 Toporowicz, „Geneza...”, 13.

${ }^{39}$ W 1868 roku gimnastyka stała się przedmiotem obowiązkowym w szkołach ludowych, zaś w roku 1873 przedmiotem nadobowiązkowym w szkołach średnich.

${ }^{40}$ Hądzelek, Wroczyński, Główne kierunki..., XXXIV.

41 Tamże, XXXIV-XXXV. 
i Walerian Sikorski. Pomimo początkowej niechęci wprowadzono do programu sokolego rywalizację sportową. Towarzystwu należy przypisać prekursorską rolę w rozwoju kilku dyscyplin sportowych: gimnastyki, kolarstwa, koszykówki, lekkoatletyki, pływania, piłki nożnej, szermierki i zapasów ${ }^{42}$.

Organizacja miała olbrzymi wpływ na rozwój kultury fizycznej nie tylko w Galicji. Stworzono szerokie zaplecze niezbędne do realizacji swych założeń przede wszystkim poprzez rozwój bazy materialnej; dzięki staraniom członków „Sokoła” powstawały liczne obiekty sportowe, głównie sale gimnastyczne przy szkołach. Budowano obiekty z zapleczem do ćwiczeń. Upowszechniano turystykę, fizjologię, higienę oraz teorię metodyki wychowania fizycznego ${ }^{43}$. Były to prekursorskie działania, których realizacja wymagała sprawności i zaangażowania wielu osób. Szczególnie trudne ze względu na gospodarczą stagnację Galicji oraz początkowy brak społecznego zainteresowania, co jeszcze mocniej podkreśla osiągnięcia lwowskiej organizacji.

Poza działalnością gimnastyczną propagowano funkcje kulturalno-oświatowe oraz ideowo-wychowawcze ${ }^{44}$. W niedługim czasie otwarto bibliotekę i czytelnię, założono również chór. Współpracowano z Towarzystwem Pedagogicznym i Towarzystwem Lekarskim, organizując wspólne narady, pokazy ćwiczeń, odczyty i wystawy. Od połowy lat 80 . zaczęto wyraźniej akcentować wątki narodowe i patriotyczne, uczestniczono również w nabożeństwach odprawianych z okazji rocznic historycznych. $\mathrm{Z}$ czasem we Lwowie zaczęto organizować we własnym zakresie obchody rocznic narodowych. Gromadziło się na nich wielu mieszkańców miasta, w tym młodzież. Zainteresowanie społeczne powodowało wzrost liczby osób wstępujących w szeregi stowarzyszenia. W 1892 roku do Towarzystwa Gimnastycznego „Sokół” należało już 1297 członków ${ }^{45}$.

Kilkunastoletnia aktywność lwowskiego Towarzystwa Gimnastycznego „Sokół” przyniosła wymierny skutek - inne miejscowości zaczęły zakładać organizacje, wzorując się na pierwowzorze. Był to sukces, szczególnie z uwagi na prowadzenie działalności pod kontrolą obcego państwa. W polskim społeczeństwie udało się zaszczepić ideę związaną z wartościami narodowymi. Pierwsza organizacja poza Lwowem powstała w 1884 roku w Stanisławowie oraz Tarnowie, zaś w następnym roku w Krakowie, Kołomyi, Przemyślu i Tarnopolu. Idea ruchu sokolego rozprzestrzeniła się wkrótce w całej Galicji. Została przeniesiona również do zaboru pruskiego.

${ }^{42}$ Stanisław Zaborniak, „Wkład Towarzystwa Gimnastycznego «Sokół» w rozwój kultury fizycznej na ziemiach polskich pod zaborem austriackim w latach 1867-1914", w: Szkice z działalności Towarzystwa Gimnastycznego „Sokół” (1867-2006), red. Stanisław Zaborniak, Paweł Kowal (Rzeszów: Wydawnictwo Uniwersytetu Rzeszowskiego 2010), 17-18, 31.

${ }^{43}$ Tamże, 12-14.

${ }^{44}$ Snopko, Dudek, „Rozwój...”, 14.

${ }^{45}$ Snopko, Polskie Towarzystwo..., 76, 82-83. 
Znaczącym osiągnięciem Towarzystwa było powstanie dużej liczby gniazd w pozbawionych inicjatywy społecznej małych miasteczkach galicyjskich. Istnienie organizacji sokolej w takich miejscach stanowiło awans kulturowy ${ }^{46}$. Prowadzona działalność w mniejszych miejscowościach charakteryzowała się większą aktywnością pozasportową. Mieszkaniec galicyjskiego miasteczka

[...] widział przede wszystkim festyny, bale, koncerty i wieczornice, które odbywały się w „Sokole”, a nie lekcje gimnastyki. W małych miejscowościach placówki organizacji ogniskowały życie towarzysko-kulturalne lokalnej inteligencji i bardziej aktywnych kręgów mieszczaństwa. Sokole zespoły artystyczne zaspokajały kulturalne aspiracje mieszkańców, wzbogacały życie duchowe i dostarczały godziwej rozrywki ${ }^{47}$.

Organizowano również przedstawienia teatralne, wycieczki i zabawy taneczne. Gniazda sokole stwarzały często jedyną okazję kontaktu z muzyką i teatrem. Podobnie jak we Lwowie, gniazda prowincjonalne organizowały obchody rocznic narodowych, starając się pobudzić ducha narodowego i przypominać o obowiązkach wobec Ojczyzny ${ }^{48}$.

Ruch sokoli zależał w głównej mierze od społeczności, która tworzyła poszczególne oddziały. W galicyjskich gniazdach przeważała inteligencja, w mniejszym stopniu drobnomieszczaństwo. Rzadko członkami oddziałów byli przedstawiciele klas posiadających, robotników i chłopów. Organizacja próbowała rozwinąć swoją działalność również w środowisku wiejskim, mając na celu aktywizowanie ludności polskiej. Placówki wiejskie działały jednak słabo, po pewnym czasie zanikały ${ }^{49}$.

W roku 1892 Towarzystwo świętowało 25-lecie swego istnienia. W związku z jubileuszem zorganizowano we Lwowie pierwszy zlot sokolstwa polskiego. Poza przedstawicielami gniazd galicyjskich przybyli również goście z zaboru niemieckiego oraz sokoli z Czech. Zlot ten miał nie tylko znaczenie propagandowe. Podczas obchodów narodziła się idea utworzenia wspólnej organizacji skupiającej istniejące gniazda. Pomysł szybko został zrealizowany. 23 grudnia 1892 roku dokonano zatwierdzenia statutu Związku Polskich Towarzystw Gimnastycznych Sokolich w Austrii. Była to organizacja nadrzędna w stosunku do stowarzyszeń na terenie Galicji. Do związku przystąpiło 46 gniazd. Pierwszym prezesem związku wybrano Tadeusza Romanowicza ${ }^{50}$.

O jedności i sile ruchu sokolego miały świadczyć organizowane zloty - do I wojny światowej odbyło się ich pięć, trzy we Lwowie, dwa w Krakowie. W działalności „Sokoła” przed odzyskaniem niepodległości wydarzenia

${ }^{46}$ Wojciech Lipoński, Historia sportu: na tle rozwoju kultury fizycznej (Warszawa: Wydawnictwo Naukowe PWN 2012), 427.

${ }^{47}$ Snopko, Dudek, „Rozwój...”, 17.

48 Snopko, Polskie Towarzystwo..., 84-86.

49 Snopko, Dudek, „Rozwój..., 19-20.

50 Terech, Zarys dziejów..., 13. 
te odgrywały szczególną rolę. Łączono je często z obchodami rocznic, miały więc szerszy kontekst patriotyczno-narodowy. Zloty stanowiły skuteczny środek propagandowy, umożliwiały zaprezentowanie się organizacji sokolej przed społeczeństwem. Przysparzały ruchowi nowych członków i sympatyków ${ }^{51}$. Pokazy i przemarsze wzbudzały często podziw mieszkańców. Poprzez swą oprawę wzmacniały uczucia patriotyczne. Szczególnym był zlot z 1910 roku - zorganizowany w pięćsetną rocznicę zwycięstwa pod Grunwaldem.

Towarzystwo Gimnastyczne „Sokół” zaczęło zdobywać coraz większą popularność. Wynikała ona nie tylko z programu wychowania fizycznego

[...] ale głównie z faktu, że „Sokół” był uważany za instytucję polskiego życia narodowego, prowadzącą pod „gimnastycznym” szyldem uniwersalną, wielokierunkową działalność społeczną i posiadającą ukryte głębiej cele niepodległościowe. W pewnych kręgach nawet wypadało należeć do tej organizacji, pokazać się czasem publicznie $\mathrm{w}$ mundurze sokolim, zwłaszcza, że w warunkach galicyjskich nie narażało to na żadne represje, a było z sympatią przyjmowane przez ludność. Ambitniejszym członkom społeczności lokalnych Towarzystwo umożliwiało pokazanie się na scenie publicznej, zaistnienie w życiu społecznym danej miejscowości i podniesienie osobistego prestiżu ${ }^{52}$.

Mimo napotykanych przeszkód lokalne środowiska podejmowały trud tworzenia nowych gniazd; wzmacniało to ruch sokoli. Była to idea łącząca Polaków $\mathrm{z}$ trzech zaborów, a także tych przebywających poza granicami kraju, którzy organizowali się wokół wspólnych wartości. Ograniczone możliwości nie zniechęcały najwierniejszych propagatorów idei sokolej. Najważniejszą wartością była niepodległa Polska.

\section{Działalność oświatowo-wychowawcza na łamach „Przewodnika Gimnastycznego «Sokół»”}

Chcąc dotrzeć do szerszych kręgów społeczeństwa, Towarzystwo Gimnastyczne „Sokół” zabiegało o możliwość wydawania własnego organu prasowego. Początkowo funkcje te pełniły okazjonalne broszury oraz publikacje w lokalnej prasie. $\mathrm{Z}$ czasem uznano, że dotychczasowe metody rozpowszechniania idei ruchu sokolego są niewystarczające. Pomimo trudności finansowych nie rezygnowano z planów. 1 kwietnia 1881 roku rozpoczęto, trwające prawie 60 lat z przerwami, wydawanie „Przewodnika Gimnastycznego «Sokół»”53.

${ }^{51}$ Jan Snopko, „I Zlot Sokolstwa Polskiego w 1892 r. we Lwowie”, w: Szkice z dziejów „Sokoła” w potudniowej i wschodniej Polsce, red. Andrzej Nowakowski (Wadowice: Drukarnia i Wydawnictwo Grafikon 2002), 6.

52 Snopko, Dudek, „Rozwój...”, 19.

53 Snopko, Polskie Towarzystwo..., 58. 
Organ prasowy miał spełniać dwie funkcje: rozpowszechniać gimnastykę, założenia i cele lwowskiego towarzystwa oraz pośredniczyć między władzami i członkami organizacji, informując o bieżących sprawach ${ }^{54}$. Czasopismo miało służyć propagowaniu gimnastyki oraz idei ruchu sokolego, trafiając do każdego, „[...] komu sprawa wychowania, zdrowia i pomyślności narodowej nie jest obojętną”"55.

W pierwszym numerze, w artykule $O d$ redakcyi, tak pisano o zadaniach pisma:

[...] rozpowszechniając rzetelne i zdrowe pojęcia o znaczeniu gimnastyki, rodzinom dać pismo, w któremby znalazły pomoc w pełnieniu głównego swego obowiązku, wychowania czerstwego i dzielnego pokolenia - szkole i ćwiczącym się zastąpić poniekąd podręczniki w tym przedmiocie, a w młodzieży wzbudzić zamiłowanie do cielesnych ćwiczeń i przypomnieć jej obowiązki, jakie na niej ciężą w tym względzie ${ }^{56}$.

Ponadto $\mathrm{w}$ artykule promowano gimnastykę, zamierzając uwydatnić jej znaczenie wychowawcze. Nawiązano do przeciążenia uczniów nauką, proponując włączenie do zajęć ćwiczeń fizycznych. Odwołano się w tym celu do harmonijnego ideału wychowania Greków oraz postępowych haseł Jędrzeja Śniadeckiego ${ }^{57}$. Znaczenie czasopisma dla rozwoju Towarzystwa Gimnastycznego „Sokół” jest niepodważalne. Stało się ono powszechną formą przekazywania informacji.

Z czasopismem współpracowali głównie pedagodzy, lekarze oraz nauczyciele gimnastyki. „Przewodnik” stał się łącznikiem gniazd sokolich. Docierał również do pozostałych zaborów oraz za granicę. Pismo szybko zyskało uznanie; o czym może świadczyć uchwała Rady Szkolnej Krajowej z 1882 roku, w której zalecono „Przewodnik” do szkolnych bibliotek oraz seminariów nauczycielskich. Nakład pisma systematycznie wzrastał ${ }^{58}$.

Wraz z rozwojem Towarzystwa zmieniał się również wydawany organ prasowy. Zawartość periodyku można podzielić w początkowym etapie na następujące grupy tematyczne: anatomia, fizjologia, higiena ruchów, teoria gimnastyki, dzieje powszechne gimnastyki, dzieje gimnastyki w Polsce, sprawozdania z działalności Towarzystwa we Lwowie oraz w Europie, bibliografia dzieł o tematyce gimnastycznej, kronika wydarzeń ${ }^{59}$. Dostosowując się do zmian, tematyka pisma ulegała powolnym przemianom.

${ }^{54}$ Czesław Michalski, „Czasopisma lwowskich i krakowskich organizacji sokolich” [dokument elektroniczny], VII Ogólnopolska Konferencja Naukowa, Kraków-Lwów. Książki, Czasopisma, Biblioteki XIX i XX Wieku (2003), 422, http://rep.up.krakow.pl/xmlui/bitstream/handle/11716/2826/34_czasopisma_lwowskich_i_krakowskich_organizacji_sokolich_c_michalski. pdf? sequence=1\&isAllowed =y (dostęp: 6.03.2019).

${ }_{55}$ Przewodnik Gimnastyczny „Sokót” 1 (1881), 2, http://www.wbc.poznan.pl/publication/35486 (dostęp: 6.03.2019).

56 Tamże.

57 Tamże.

58 Snopko, Polskie Towarzystwo..., 59.

${ }_{59}$ Bogdan Tuszyński, „Prasa Towarzystwa Gimnastycznego «Sokół» w trzech zaborach”, Kwartalnik Historii Prasy Polskiej 24/4 (1985-1986), 29. 
Pismo miało istotne znaczenie w wychowaniu sokołów, w działalności oświatowo-kulturalnej, gimnastyczno-sportowej oraz propagandowo-informacyjnej. Składało się z działu urzędowego, korespondencyjnego, kronikarskiego oraz rubryki „Wolne głosy”. Na łamach czasopisma informowano o działalności władz sokolich, najważniejszych wydarzeniach, a także postanowieniach władz państwowych oraz sportowych. Zamieszczano w nim również artykuły oświatowo-historyczne. Znaczna część informacji dotyczyła zawodów sportowych oraz osiągnięć sportowców „Sokoła” ${ }^{60}$.

„Przewodnik Gimnastyczny «Sokół»” odegrał znaczącą rolę w propagowaniu i rozwoju lekkoatletyki. Czasopismo dla organizacji sokolej oraz szkolnictwa pełniło funkcję przewodnika metodycznego i regulaminowego. Drukowanie w nim instrukcji z informacjami o właściwym sposobie wykonywania czynności odpowiednich dla poszczególnych dyscyplin powodowało, że wiedza ta była znana szerszemu gronu. Tym samym gimnastyka sokola odegrała pionierską rolę w początkowym okresie rozwoju sportu na ziemiach polskich ${ }^{61}$. Z biegiem czasu doceniono rozwijające się dyscypliny sportowe, które były początkowo traktowane z dystansem. Zaczęto dostrzegać wypływające ze sportu takie cechy jak waleczność oraz współzawodnictwo. Wychowawcom wyznaczono zadanie „[...] ażeby ta walka odbywała się w sposób uprzejmy"62.

Propagowanie gimnastyki oraz rozwijających się dyscyplin sportowych na łamach czasopisma dotyczyło wychowania do sprawności fizycznej człowieka, obywatela, w zamierzeniach patrioty i żołnierza. Już wkrótce promowanie rozwoju wychowania fizycznego przyniosło wymierny rezultat w postaci polepszenia tężyzny fizycznej Polaków.

Na łamach czasopisma upowszechniano również ideę olimpijską. Informowano o najważniejszych wydarzeniach, które miały miejsce podczas igrzysk olimpijskich począwszy od 1896 roku. Publikowano artykuły, w których zwalczano alkoholizm i nikotynizm, opisywano działania profilaktyczne przeciwko chorobom ${ }^{63}$.

O znaczeniu czasopisma w rozwoju wychowania fizycznego na ziemiach polskich świadczą słowa dziennikarza Rudolfa Wacka, który we Lwowie przyglądał się działalności Towarzystwa Gimnastycznego „Sokół”:

Przez długie lata jedyne to czasopismo, poświęcone fachowemu roztrząsaniu spraw wychowania fizycznego, jedyne dziś źródło do badań [...] „Przewodnik” [...] tłumaczy, stara się zainteresować ciekawość publiczną, jest sprawozdawcą i pierwszym recenzentem w Polsce. Kto dziś chce dotrzeć do pierwszych u nas źródeł myśli

${ }^{60}$ Krzysztof Stryjkowski, „Działalność kulturalna, oświatowa i prasowo-wydawnicza”, w: Zarys dziejów Sokolstwa Polskiego..., 149.

${ }^{61}$ Zaborniak, „Wkład Towarzystwa...”, 28, 29.

${ }^{62}$ Przewodnik Gimnastyczny „Sokól” 11 (1911), 86, http://www.wbc.poznan.pl/publication/35486 (dostęp: 6.03.2019).

${ }^{63}$ Zaborniak, „Wkład Towarzystwa..., 33, 35. 
wychowania fizycznego społeczeństwa, kto chciałby zbadać rozwój ćwiczeń cielesnych naszej młodzieży, kto chciałby poznać pierwsze wyczyny sportowe w Polsce, ten to wszystko znajdzie w „Przewodniku” i w dodawanym do niego od 1905 r. „Dodatku fachowym" ${ }^{\prime 6}$.

$\mathrm{Z}$ biegiem lat znaczenie czasopisma rosło. Było to również widoczne w systematycznie zwiększającym się nakładzie. W pierwszym roku wynosił on 500 egzemplarzy, a przed I wojną światową przekroczył 20 tysięcy ${ }^{65}$. W dwudziestoleciu międzywojennym wydawano około 60 tysięcy egzemplarzy ${ }^{66}$. Obok funkcji popularyzatorskich pismo było wewnętrznym organem "Sokoła”. Stąd liczne odezwy, protokoły, uchwały, regulaminy, programy, ankiety i ogłoszenia.

Publikowane zagadnienia na łamach pisma często uzależnione były od zmian zachodzących w polityce. Nie ulega jednak wątpliwości, że głównym zadaniem było zainteresowanie ideą ruchu sokolego. W tym celu wprowadzono kilka zmian. Było to możliwe głównie dzięki nowoczesnemu spojrzeniu na czasopismo. Nawiązano ścisłe kontakty i współpracę z autorami zagranicznymi oraz ze środowiskiem lekarskim. Zaczęto publikować w przystępnym języku, docierając tym samym do większej liczby odbiorców. Były to m.in. artykuły i wspomnienia dotyczące wydarzeń $\mathrm{z}$ historii Polski. Opisywano zloty sokole, pokazy oraz ćwiczenia, uświadamiając dążenia narodowe Polaków ${ }^{67}$. Wszystko to przyczyniało się do kształtowania za pośrednictwem „Przewodnika” idei ruchu sokolego.

Na łamach wydawanego czasopisma Towarzystwa Gimnastycznego „Sokół” promowano gimnastykę wychowawczą, która wyrabia przymioty ducha i potęguje siłę woli. Oparta jest na ruchach zgodnych z możliwościami ludzkiego organizmu. Celami gimnastyki wychowawczej były: zdrowie, zręczność, zgrabność oraz wyrobienie cnót obywatelskich. Gimnastyka przez cały czas działalności Towarzystwa Gimnastycznego „Sokół” stanowiła źródło wartości wychowawczych.

W rezultacie „Przewodnik Gimnastyczny” - podstawowy organ prasowy lwowskiej organizacji - jawi się jako bogaty zasób artykułów, wciąż jeszcze nieodkrytych. Zawiera bowiem cenny historycznie materiał opisowy odnoszący się do przeszłości polskiej myśli pedagogicznej. Myśl wychowawczą można odnajdywać w propagowanych na łamach „Przewodnika Gimnastycznego «Sokół»” ideałach, np. nawiązujących do starożytnego ideału kalokagatii.

${ }^{64}$ Michalski, „Czasopisma...”, 424.

${ }^{65}$ Kuriańska-Wołoszyn, Nowak, Gimnastyka..., 41.

${ }^{66}$ Stryjkowski, „Działalność...”, 149.

67 Tuszyński, „Prasa..., 32. 


\section{Ostatnie lata niewoli}

Przed wybuchem I wojny światowej „Sokół” przeżywał poważny kryzys. Problemy dotyczyły spraw organizacyjnych, sfery programowej oraz ideowego określenia. Zaniedbano pracę na wsi i wśród młodzieży robotniczej. Działalność zaczęła przybierać charakter towarzyski; zajęcia $\mathrm{z}$ gimnastyki schodziły na dalszy plan. Popularność wśród młodzieży zyskiwały organizacje propagujące ćwiczenia wojskowe. Rosło znaczenie ruchu zarzewiackiego i strzeleckiego ${ }^{68}$.

Kryzys wynikał także ze zmiany sytuacji społeczno-politycznej. Niezbędne stało się wytyczenie nowych kierunków działania. Wysuwano postulaty zmierzające do wprowadzenia zajęć gimnastyczno-wojskowych, nawiązania współpracy z istniejącymi organizacjami przysposobienia wojskowego. Ćwiczenia miały zmienić swój charakter $\mathrm{z}$ wychowawczego i zdrowotnego na utylitarny. Wychowanie fizyczne miało być traktowane jako środek prowadzący do tworzenia kadr wojskowych. Lwowscy działacze nie widzieli jednak potrzeby zmian ${ }^{69}$.

Organizacja była krytykowana ze względu na swój pacyfizm. Zarzucano, że działalność gimnastyczno-sportowa nie zachęca do walki. „Pierwiastka wojskowego niewiele było w sokolstwie, choć właśnie te elementy były często eksponowane. Zupełnie nową jakość, jeśli chodzi o szkolenie wojskowe członków, przyniosło dopiero utworzenie Stałych Drużyn Sokolich"70. Nastąpiło to $\mathrm{w} 1912$ roku - włączono się tym samym w proces rozwoju przysposobienia wojskowego ${ }^{71}$.

Hasła propagowane przez sokolstwo - „Mens sana in corpore sano” oraz „Wszystko dla Ojczyzny”72 - przyniosły upragnioną wolność. Polska odzyskała niepodległość - cel został osiągnięty. Towarzystwo Gimnastyczne „Sokół” odegrało ważną rolę w realizacji marzeń wielu pokoleń. Prowadząc swą wieloaspektową działalność, ruch sokoli wpłynął na wszechstronne przygotowanie ludności, zarówno pod kątem wzrostu biologicznej żywotności, jak i świadomego podjęcia decyzji o walce zbrojnej ${ }^{73}$. Liczny udział sokołów w bojach o odzyskanie niepodległości przyniósł znaczący wkład w końcowy sukces.

Długoletni proces odzyskiwania niepodległości zakończył ponad pięćdziesięcioletni etap w historii ruchu sokolego. Nielicznym pamiętającym powołanie Towarzystwa Gimnastycznego „Sokół” we Lwowie w 1867 roku było dane doczekać

${ }^{68}$ Dobiesław Dudek, Działalność wojskowa Towarzystwa Gimnastycznego „Sokól” przed I wojna światowa (Nowy Sącz: Sądecka Oficyna Wydawnicza Wojewódzkiego Ośrodka Kultury 1994), 6-8.

${ }^{69}$ Dudek, Działalność..., 8-13.

${ }^{70}$ Snopko, Polskie Towarzystwo..., 215.

${ }^{71}$ Dobiesław Dudek, „«Sokół» na tle przygotowań niepodległościowych w Galicji”, w: $Z$ dziejów Towarzystw Gimnastycznych..., 41.

72 Przewodnik Gimnastyczny „Sokól” 6 (1919), 22, http://www.wbc.poznan.pl/publication/35486 (dostęp: 6.03.2019).

${ }^{73}$ Lipoński, Historia..., 429. 
tej chwili. Działalność prowadzona przez tak długi okres miała olbrzymi wkład na zachowanie i utrwalenie tradycji narodowych i wychowanie nowej generacji, której przyszło uczestniczyć w odbudowie państwa polskiego.

\section{Podsumowanie}

Towarzystwo Gimnastyczne „Sokół”, od momentu powstania do wybuchu I wojny światowej, ulegało zmianom. Wynikało to z rozwoju organizacyjnego i podejmowania nowych form aktywności. Z biegiem lat rozbudowano program ćwiczeń fizycznych, działalność wzbogacono również o wątki patriotyczne. Skupiano się na celach wychowawczych. Propagowano wartości narodowe oraz pracę na rzecz społeczeństwa. Dużą wagę przywiązywano do kwestii moralnych, pamiętano o bohaterach z przeszłości, najważniejszych wydarzeniach oraz rocznicach. Integracja i identyfikacja członków poszczególnych gniazd stała się ważną kwestią dla organizacji. Dbano o zachowanie i pielęgnowanie tożsamości narodowej. Kształtowano przyszłe pokolenia, zachęcając do zaangażowania i wzięcia odpowiedzialności za losy kraju. W momencie przełomowym miały być gotowe do walki o niepodległość. Dostrzegano w nich nadzieję na lepszą przyszłość.

Następnym etapem działalności organizacji był udział w budowie niepodległej ojczyzny. Poprzez kontynuowanie swej idei w II Rzeczpospolitej ruch sokoli ponownie zapisał się na kartach polskiej historii. Już wkrótce na skutek wybuchu II wojny światowej kolejne pokolenie sokołów stanęło z bronią w ręku do walki o wolną ojczyznę. Wielu z nich zapłaciło najwyższą cenę.

Streszczenie: W artykule przedstawiono rozwój Towarzystwa Gimnastycznego „Sokół” powstałego w 1867 roku we Lwowie. Swym zasięgiem nowa idea w ciągu kilkunastu lat objęła obszar Galicji, przenikając również do pozostałych zaborów. Działalność Towarzystwa rozwijała się także w okresie dwudziestolecia międzywojennego. Istotny wpływ na wzrost popularności ruchu sokolego miało wydawane od 1881 roku czasopismo „Przewodnik Gimnastyczny «Sokół»". Umożliwiało ono m.in. propagowanie gimnastyki oraz najważniejszych haseł organizacji. Stanowiło również funkcję łącznika pomiędzy Lwowem a licznie powstającymi filiami, tzw. gniazdami. Łacińska dewiza „Mens sana in corpore sano” („W zdrowym ciele zdrowy duch”) stała się hasłem przewodnim prowadzonej działalności. Towarzystwo odegrało znaczącą rolę w upowszechnianiu gimnastyki oraz wielu dyscyplin sportowych. Gniazda stały się również ośrodkami oświatowo-kulturowymi. Promując kulturę fizyczną, wychowywano oraz przekazywano treści patriotyczne kolejnym pokoleniom.

Słowa kluczowe: Towarzystwo Gimnastyczne „Sokół”, „Przewodnik Gimnastyczny «Sokół»”, ruch sokoli, działalność sportowa, działalność wychowawcza, Galicja 


\section{Bibliografia}

Buszko, Józef. Galicja 1859-1914. Polski Piemont? Warszawa: Krajowa Agencja Wydawnicza, 1989.

Buszko, Józef. Od niewoli do niepodległości (1864-1918). Kraków: Forga Oficyna Wydawnicza, 2001.

Dudek, Dobiesław. Działalność wojskowa Towarzystwa Gimnastycznego „Sokót” przed I wojna światową. Nowy Sącz: Sądecka Oficyna Wydawnicza Wojewódzkiego Ośrodka Kultury, 1994.

Dudek, Dobiesław. „«Sokół» na tle przygotowań niepodległościowych w Galicji”. W: Z dziejów Towarzystw Gimnastycznych „Sokół”, red. Zdzisław Pawluczuk. Gdańsk: Wydawnictwo Pionier, 1996, 39-44.

Gizowski, Mariusz. „Symbolika ideograficzna sokolstwa polskiego”. W: 130 lat Sokolstwa Polskiego, Polskie Towarzystwo Gimnastyczne „Sokół”, red. Andrzej Łopata. Kraków: Polskie Towarzystwo Gimnastyczne „Sokół”, 1997, 35-44.

Grodziski, Stanisław. W Królestwie Galicji i Lodomerii. Kraków: Wydawnictwo Literackie, 1976.

Hądzelek, Kajetan, Wroczyński, Ryszard. Główne kierunki rozwoju wychowania fizycznego od końca XVIII wieku do 1918 roku. Wrocław: Zakład Narodowy im. Ossolińskich - Wydawnictwo, 1968.

Kieniewicz, Stefan. Galicja w dobie autonomicznej (1850-1914): wybór tekstów. Wrocław: Wydawnictwo Zakładu Narodowego im. Ossolińskich, 1952.

Kuriańska-Wołoszyn, Joanna, Nowak, Leonard. Gimnastyka w Polsce w latach 1919-1939. Poznań: Wydawnictwo WSPiA, 2013.

Lipoński, Wojciech. Historia sportu: na tle rozwoju kultury fizycznej. Warszawa: Wydawnictwo Naukowe PWN, 2012.

Snopko, Jan. Polskie Towarzystwo Gimnastyczne „Sokól” w Galicji 1867-1914. Białystok: Wydawnictwo Uniwersytetu w Białymstoku, 1997.

Snopko, Jan. „I Zlot Sokolstwa Polskiego w 1892 r. we Lwowie”. W: Szkice z dziejów „Sokoła” w południowej i wschodniej Polsce, red. Andrzej Nowakowski. Wadowice: Drukarnia i Wydawnictwo Grafikon, 2002, 6-11.

Snopko, Jan, Dudek, Dobiesław. „Rozwój ruchu sokolego w zaborze austriackim”. W: Zarys dziejów Sokolstwa Polskiego w latach 1867-1997, red. Eligiusz Małolepszy, Zdzisław Pawluczuk. Częstochowa: Wydawnictwo WSP, 2001, 13-29.

Stryjkowski, Krzysztof. „Działalność kulturalna, oświatowa i prasowo-wydawnicza”. W: Zarys dziejów Sokolstwa Polskiego w latach 1867-1997, red. Eligiusz Małolepszy, Zdzisław Pawluczuk. Częstochowa: Wydawnictwo WSP, 2001, 133-150.

Toporowicz, Kazimierz. „Geneza Towarzystwa Gimnastycznego «Sokół» na ziemiach polskich. Powstanie «Sokoła» we Lwowie". W: Zarys dziejów Sokolstwa Polskiego w latach 1867-1997, red. Eligiusz Małolepszy, Zdzisław Pawluczuk. Częstochowa: Wydawnictwo WSP, 2001, 9-13.

Toporowicz, Kazimierz. „Zarys dziejów «Sokoła» na ziemiach polskich w latach 1867-1947”. W: Z dziejów Towarzystw Gimnastycznych „Sokół”, red. Zdzisław Pawluczuk. Gdańsk: Wydawnictwo Pionier, 1996, 7-19.

Tuszyński, Bogdan. „Prasa Towarzystwa Gimnastycznego «Sokół» w trzech zaborach”. Kwartalnik Historii Prasy Polskiej 24/4 (1985-1986), 27-48.

Wroczyński, Ryszard. Powszechne dzieje wychowania fizycznego i sportu. Wrocław: Wydawnictwo BK, 2003.

Zaborniak, Stanisław. „Wkład Towarzystwa Gimnastycznego «Sokół» w rozwój kultury fizycznej na ziemiach polskich pod zaborem austriackim w latach 1867-1914". W: Szkice z działalności Towarzystwa Gimnastycznego „Sokól” (1867-2006), red. Stanisław Zaborniak, Paweł Kowal. Rzeszów: Wydawnictwo Uniwersytetu Rzeszowskiego, 2010, 11-35.

Zgórniak, Marian. Polska w czasach walk o niepodległość (1815-1864). Kraków: Forga Oficyna Wydawnicza, 2001. 


\section{Netografia}

Księga pamiątkowa ku uczczeniu dwudziestej piątej rocznicy założenia Towarzystwa Gimnastycznego „Sokót” we Lwowie, autor wstępu Tadeusz Romanowicz. Lwów: Nakładem Towarzystwa Gimnastycznego „Sokół”, 1892, https://www.sbc.org.pl/dlibra/publication/10742/edition/10264/ content (dostęp: 6.03.2019).

Michalski, Czesław. „Czasopisma lwowskich i krakowskich organizacji sokolich” [dokument elektroniczny], VII Ogólnopolska Konferencja Naukowa, Kraków-Lwów. Książki, Czasopisma, Biblioteki XIX i XX Wieku (2003), http://rep.up.krakow.pl/xmlui/bitstream/handle/11716/2826/34_czasopisma_lwowskich_i_krakowskich_organizacji_sokolich_c_michalski. pdf? sequence $=1$ \&isAllowed $=y$ (dostęp: 6.03.2019).

Przewodnik Gimnastyczny „Sokót” 1 (1881), 1-12, http://www.wbc.poznan.pl/publication/35486 (dostęp: 6.03.2019).

Przewodnik Gimnastyczny „Sokót” 11 (1911), 81-88, http://www.wbc.poznan.pl/publication/35486 (dostęp: 6.03.2019).

Przewodnik Gimnastyczny „Sokól” 6 (1919), 22-28, http://www.wbc.poznan.pl/publication/35486 (dostęp: 6.03.2019).

Statut Towarzystwa Gimnastycznego we Lwowie (Lwów 1867), http://dlibra.biblioteka.tarnow.pl/ Content/697/sk_46_02.pdf (dostęp: 6.03.2019).

Szczepanowski, Stanisław. Nędza Galicyi w cyfrach i program energicznego rozwoju gospodarstwa krajowego. Lwów: nakładem autora, 1888,

https://www.sbc.org.pl/dlibra/publication/37606/edition/34263/content?ref=desc (dostęp: 6.03.2019).

Terech, Michał. Zarys dziejów sokolstwa polskiego. Warszawa: Nakładem Związku Towarzystw Gimnastycznych „Sokół” w Polsce, 1932, http://www.wbc.poznan.pl/dlibra/plain-content?id=273583 (dostęp: 6.03.2019). 